\title{
Preliminary Research on the Wheat Pests and on Their Integrated Control during 2015-2016, at Agricultural Research-Development Station Turda
}

\author{
Ionel Dragoş DĂRAB ${ }^{1}$, Dana MALSCHI*2,3, Ana-Maria VĂLEAN² ${ }^{2}$, Adina Daniela TĂRĂU², Cornel CHEŢAN \\ ${ }^{2}$, Ion OLTEAN ${ }^{1}$ \\ ${ }^{1}$ Department Environment and Plant Protection.University of Agricultural Sciences and Veterinary \\ Medicine Faculty of AgricultureCluj-Napoca, Romania. \\ ${ }^{2}$ Agricultural Research and Development Station Turda, Cluj County, România, \\ ${ }^{3}$ Babeș-Bolyai University, Environmental Science and Engineering Faculty Cluj-Napoca \\ *Corresponding author: danamalschi@yahoo.com
}

Bulletin USAMV series Agriculture 74(1)/2017

Print ISSN 1843-5246; Electronic ISSN 1843-5386

DOI 10.15835/buasvmcn-agr: 12652

\begin{abstract}
In Transylvania, the evolution of wheat insect pests is strongly influenced by the ecotehnological conditions, by climate change and current technology (Malschi, 2009 Malschi et al., 2015). The paper presents the dynamics and importance of the main pests of wheat (thrips, aphids, leafhoppers, wheat flies, cereals sunbugs, investigated under the integrated pest control system suitable of the area. During 2015-2016, the investigations were conducted at the Agricultural Research and Development Station Turda, from the wheat no tillage cultural system with cereal rotation of three years and applying all zonal recommendations of technology and phytosanitary complex. The pest monitoring was performed based on the samples collected with entomological net, by decadal 100 sweep-net catches/sample. The study data shows the danger of the attack of abundant populations of wheat flies (Phorbia securis, Delia coarctata, Opomyza florum, Oscinella frit etc.; wheat fleas (Chaetocnema aridula) and cereal leaf beetle (Oulema melanopa); leafhoppers (Psammotettix alienus, Javesella pellucida, Macrosteles laevis); aphids (Sitobion avenae, Schizaphis graminum, Rhopalosiphum padi); thrips (Haplothrips tritici), sunbugs (Eurygaster maura, Aelia acuminata) etc., and the necessity of applying insecticide treatments on the vegetation.

Since 2015, a stronger impact of global warming on the wheat pests structure (\%) are found. This change began on the last ten years. The importance of cereal sunbugs is increasing, well as the importance of the wheat flies, aphids and leafhoppers, which requires professional study on the pest dynamics and adequate integrated control of wheat pests.
\end{abstract}

Keywords: wheat flies, thrips, aphids, leafhoppers, sunbugs

\section{INTRODUCTION}

The evolution of wheat insect pests in Transylvania is strongly influenced by the eco-tehnological conditions (Malschi, 2007, 2009, Malschi et al., 2015). In the last years the research conducted at Agricultural Research and Development Station Turda, revealed the main groups of pests of wheat: Thysanoptera, Diptera, Homoptera (aphids and leafhoppers), Coleoptera,
Heteroptera etc. and the importance of integrated control of them (Malschi Dana, 1995, 2000, 2001, 2003, 2007, 2008, 2009 a, b, 2014; Malschi et al. 2003; 2009; 2010; 2011; 2012), according to other data from the literature (Oltean et al. 2004; Perju, Malschi, 2001; Perju, Mustea, Malschi, 2001; Popov et al. 2005; Porca, Oltean, 2004; Rosca et al., 2011). 
Tab. 1. The integrated protection systems of wheat crops from the lots of observationand testing at ARDS Turda, during 2015 - 2016

\begin{tabular}{|c|c|}
\hline \multicolumn{2}{|c|}{ Phenology of culture and application of complex treatments } \\
\hline 2015 & 2016 \\
\hline Wheat variety: ANDRADA, & Wheat variety: ANDRADA, \\
\hline Preceding plant: Soybean & Preceding plant: Soybean \\
\hline Density of sowing: 600 germinable grains $/ \mathrm{m}^{2}$ & Density of sowing: 550 germinable grains $/ \mathrm{m}^{2}$ \\
\hline Administered fertilizers: & Administered fertilizers: \\
\hline InAutumn:NPK(18:46:0), 200 kg/ha. & In Autumn: NPK(18:46:0) 200 kg/ha+Seedsprint 25kg/ \\
\hline In the Spring: NH NO (33,3\% s.a) $150 \mathrm{~kg} / \mathrm{ha}$. & ha; In the Spring: $N-150 \mathrm{~kg} / \mathrm{ha}$. \\
\hline Sowing time:15.10.2014. Emergence: 24.10 .2014 . & Sowing time:08.10.2015. Emergence: 20.10.2015. \\
\hline Beginning of tillering: 16.11 .2014 & Beginning of tillering: 15.11.2015. \\
\hline Density: 560 plants / $\mathrm{m}^{2}$ & Density: 550 plants $/ \mathrm{m}^{2}$ \\
\hline First Treatment: at Herbicidal appl.: 19.04.2015 & First Tratament : at Herbicidal appl.: 6.04.2016 \\
\hline Herbicide: Sekator 0,15 l/ha, DMA $6-0.6$ l/ha + & Herbicide: Floramix $0.260 \mathrm{~kg} / \mathrm{ha}+\mathrm{DASH} 0.5 \mathrm{l} / \mathrm{ha}$ \\
\hline Foliar fertilizer: Agrofeed 19:19:19 4 kg/ha + & Foliar fertilizer: : Synergizer 2.5 l/ha \\
\hline Insecticide: Calypso $0.1 \mathrm{l} / \mathrm{ha}+$ & Insecticide: Biscaya $0.2 \mathrm{l} / \mathrm{ha}+$ \\
\hline Fungicide: Falcon 460 - 0.7 l/ha. & Fungicide: Falcon PRO 0.8l/ha \\
\hline Tratament 2. At flag leaf/ear appar.25.05.2015 & Tratament 2. At flag leaf/ear appar.: 19.05.2016 \\
\hline Insecticide: Fastac $0.1 \mathrm{l} / \mathrm{ha}+$ & Insecticide: Fastac $0.11 / \mathrm{ha}$ \\
\hline Fungicide: Evolus 11/ha + & Fungicide: Evolus 1l/ha \\
\hline Foliar fertilizer: Agrofeed 19:19:19 $4 \mathrm{~kg} / \mathrm{ha}$ & Foliar fertilizer: Agrofeed 3kg/ha \\
\hline
\end{tabular}

In the recent years, the research of ARDS Turda have indicated the importance of adjusting the technology of integrated pests management (IPM) to the structural changes of harmful entomofauna, which is highlighted in relation to climatic warming and increased aridity, by higher abundance of wheat thrips (as eudominant species), wheat flies Chloropidae, leafhoppers, aphids, wheat fleas (as dominant groups), cereals bugs, etc. IPM recommends special attention to preventing measures for zone specific pests: cereal flies, leafhoppers, aphids, thrips, etc., by respecting the optimal sowing time, agro-technical methods, seed treatment with systemic insecticides and complex plant protection measures. Due to increased aridity and climate warming, the critical attack moments were recorded 3-4 weeks earlier and overlapped (Malschi et al. 2013 a, b; 2014; 2015 a, b, c, d, f; 2016 a, b).

During 2015-2016 periode, some of long term research which is performed at ARDS Turda in the last of 40 years, were continued by the present study.

\section{MATERIAL AND METHODS}

The investigations were conducted in wheat crops: in no tillage cultural system with a three years cereal rotation, applying all zonal recommendations of technology and phytosanitary complex, during 2015-2016, (Tab.1).

The pest monitoring was performed based on the samples collected with entomological net, by decadal 100 sweep-net catches / sample.

Have been studied the species inventory, according the morphological /biological / ecological / geographical criteria and populations abundance and dynamics / according to the density factors (technological, climatic, biological limiters / entomophagous).

The variants from experimental lots included different treatment moments: $\mathrm{T} 1$ (at the end of tillering in the 25-33 DC stage, at herbicides time) and T2 (at flag leaf stage and ear appearancein the 45-59 DC stage); and the variants of treated lots in large experimental plots of $0.5 \mathrm{Ha}\left(5000 \mathrm{~m}^{2}\right)$ : $\mathrm{V} 1=$ untreated; $\mathrm{V} 2=$ treated with pyrethroids at $\mathrm{T} 1 ; \mathrm{V} 3=$ treated with pyrethroids at $\mathrm{T} 1+\mathrm{T} 2 ; \mathrm{V} 4$ $=$ treated with neonicotinoid at $\mathrm{T} 1+$ treated with pyrethroids at $\mathrm{T} 2$.

The determination of species, the tables with species decadal dynamics and annual abundance, the pests and entomophagus annual structure (tab. 2 , Fig 2, 3, 4), the immediate biological efficiency after insecticidal treatment and the total long term efficiency of treatments, the entomophagus mortality after the treatments (Fig. 5, 6, 7, 8, 9), 
and the variance analysis for production data with Polifact Programme (Tab. 3, 4; Fig. 10) were carried out.

\section{RESULTS AND DISCUSSIONS}

In the last 10 years, the data on the pests structure of wheat crops at ARDS Turda show: the dominance of thrips - 57\%, the numerical importance of dangerous populations of Chrysomelidae - 10\% (Oulema, Chaetocnema etc.); of aphids - $14 \%$ and leafhoppers - 4\%, of wheat flies $-12 \%$ and sunbugs - $2 \%$. The pest abundance represents a risk situations in wheat fields. Into the structure of arthropods fauna collected with entomological net, an weight of $14 \%$ only presents the beneficial entomophagous (Malschi et al. 2015).

The paper presents the dynamics and importance of the main wheat pests (thrips, aphids, leafhoppers, wheat flies, leaf beetles, wheat fleas, cereals sunbugs etc., investigated under the integrated pest control system suitable of the area, depending to: climate changes, current technology and different insecticides application. The data of study shows the danger of the abundant pest populations of wheat flies (Phorbia securis, Delia coarctata, Opomyza florum, Oscinella frit etc.; wheat fleas (Chaetocnema aridula) and cereal leaf beetle (Oulema melanopus); leafhoppers (Psammotettix alienus, Javesella pellucidaetc.); aphids (Sitobion avenae, Schizaphis graminum, Rhopalosiphum padi etc.); thrips (Haplothrips tritici),sunbugs (Eurygaster maura, Aelia acuminata etc.) and the necessity of applying insecticide treatments on the vegetation.

In accordance with previous research the paper shows the importance of insecticide applications at two different moments: at the end of tillering phase and at ear emergence. At the first treatment, the pest groups that focus on spring crops (cereal flies, fleas, leafhoppers, thrips, bugs, etc.) are controlled simultaneously, by recommending the shock and systemic insecticides (pyrethroids, neonicotinoid etc.) at the herbicides application. At the second treatment moment, the ear pests (thrips, aphids, bugs, etc.) are controlled simultaneously and shock insecticides (pyrethroids etc.) with a low negative effect on the entomophag arthropod fauna, are recommeded (Malschi et al. 2012; 2013 a, b; 2014; 2015 a, b, c, d, f; 2016 a, b).
The climate condition in 2015-2016 indicate an increase of the average temperature in the all months of spring and summer. Rainfall shows the characteristic aspects of wettest years toward normal (Fig. 1). Climatic condition, especialy the climate warming are very important for the development of entomofauna. The population increasing of Diptera, aphids, leafhoppers, leaf beetle, wheat fleas, sunbugs, thrips etc. has caused by climate warming (Tab.2).

The investigations revealed new data on the changes concerning the structure (\%) of wheat pests in 2015 and 2016, at ARDS Turda, comparatively with the average of pest structure by the past 10 years (Malschi et al. 2015, 2016):

- a higher share of aphids from 52\% and $20 \%$ comparatively with the $14 \%$ from the past 10 years;

- a higher percent share of wheat flies (24-27\%) comparatively with the $12 \%$ from the past 10 years;

- a higher share of leafhoppers (10-18\%), values which are much higher than the average of $4 \%$ of the last 10 years;

- the structure percent of sun bugs achieved an average increase of up to $4 \%$ in 2016 , values which are higher than the average of $2 \%$ of the last 10 years;

- a smaller percent share of the thrips at $7 \%$ and $17 \%$ ), values which are much lower than the average of $57 \%$ of the last 10 years (Fig. 2).

The structure (\%) of entomophagus (Fig. 3) has been established highlighting the all groups also known in the scientific literature and signaled in the previous years (Malschi, 2007) from ARDS Turda: Aranea and predators insects: Coccinellidae, Cantharidae, Malachiidae, Staphylinidae, Nabidae, Chrysopidae, Empididae, Syrphidae etc. and parasitical Hymenoptera.

Given all these pest population increases and the favorable conditions of vegetation, temperature and humidity conditions, have been developed the entomophagous populations, natural limiting of the main pests. Especially the abundance of thrips adults and larvae was much reduced as compared to the situation of the past 10 years. There has been evidenced a fort limmitation of thrips by the impportant predators of Diptera Empididae (Platipalpus). There has been evidenced the increases of the aphidophagus species abundance, especially of aphids parasites and of different 

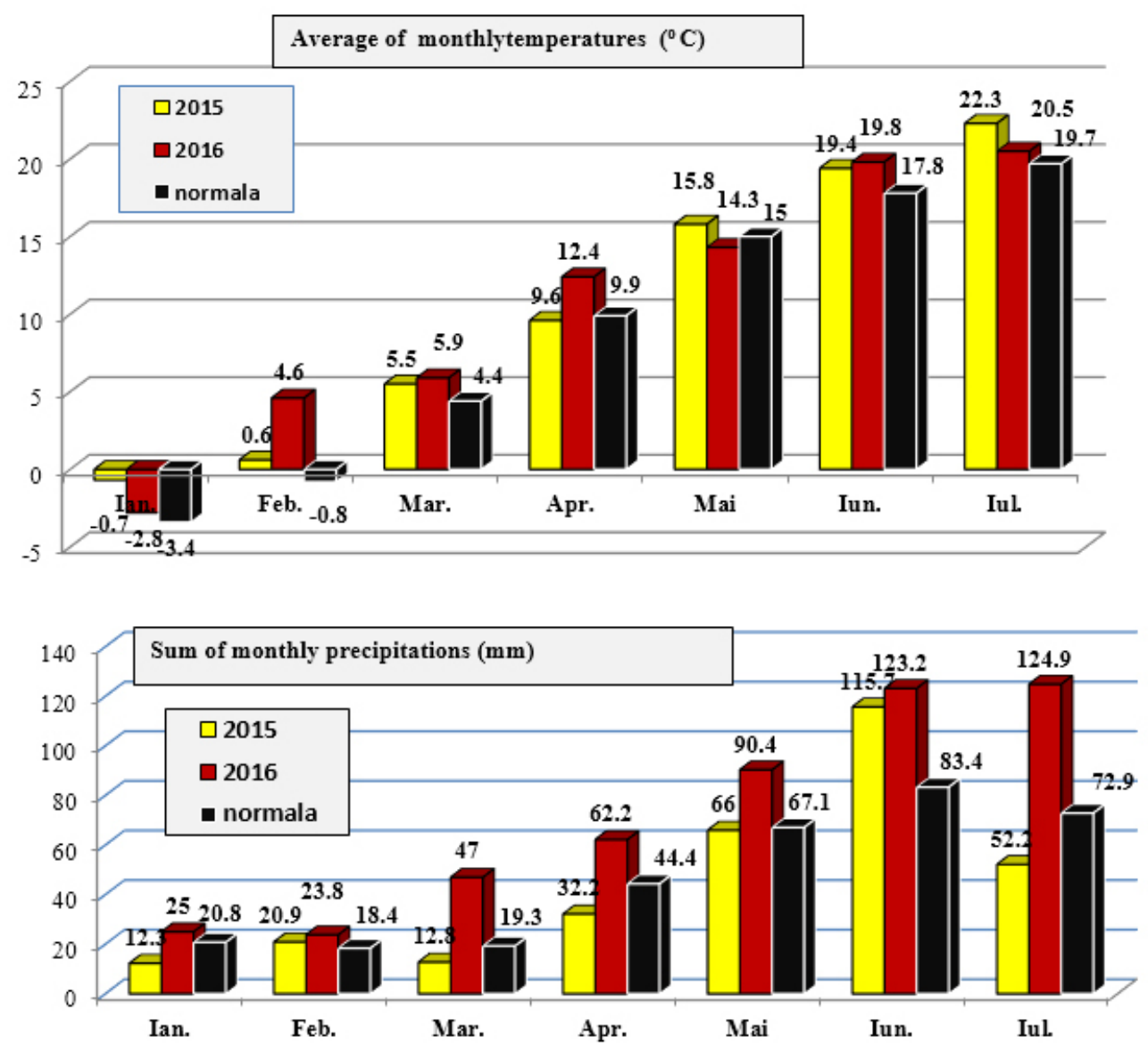

Fig. 1. Average of monthly temperatures $\left({ }^{\circ} \mathrm{C}\right)$ and sum of monthly precipitations $(\mathrm{mm})$.

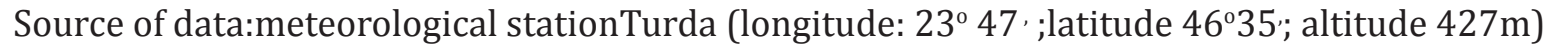

predators (Syrphidae, Coccinellidae, Malachiidae, Chrysopidae, Nabidae, Aranea etc.) (Fig 3, 4, 5).

Can observe a an important growth in the structural share of entomophages arthropod fauna collected, from $14 \%$ in the last 10 years at $21.85 \%$ and $29.85 \%$ in 2015 and 2016 respectively. The application of two treatments with insecticides on experimental variants has affected the entomophages annual abundance, especially on the case of variant V4 which included the treatment with neonicotinoid at the moment T1.

But it is highlighted that in the conditions of 2015, the two treatments with pyrethroids from V2 have been protective for the entomophagous, their percentage being higher compared to the untreated control (Fig. 4).

The integrated pest control system, adequated at the climate changes and eco-technological facthors, need to contain the application of insecticides treatments (neonicotinoides and pyrethroi- des), in two moments of treating (at herbicides time and at flag leaf stage and ear appearance).

First insecticidal treatment is recommended in April, at the end of tillering in the 25-33 DC stage (at herbicidal treatment) using systemic insecticides: neonicotinoids to control wheat flies and wheat fleas (Chaetocnema), Oulema adults, leafhoppers and sun bugs. At this moment, entomophagous were at the beginning of field occurrence and less exposed to insecticides (Fig. $6,7)$.

The second treatment is recommended at the flag-leaf appearance and ear emergence, in the 4559 DC stage, in May 10-15, to control wheat thrips adults (Haplothrips tritici), aphids, bugs and other pests, using pyrethroids etc. with an immediate control of the pest complex, with along time effect and efficiencies against the development of thrips larvae on the ears, resulting in yield increases (Fig. $5,7,8)$. 
Tab. 2. Abundance of phytophagus and entomophagus depending on insecticide treatments applied at wheat crops at ARDS Turda, during 2015 and 2016). Treatment moments: T1 (at herbicides time) and T2 (at the ear emergence); Lot variants: V1=untreated; V2=treated with pyrethroids (Fastac) at T1+T2; V3 = treated at T1 with neonicotinoid (Calypso or Biscaya) + T2 with pyrethroids. (Exemplary number colected by decadal 100 sweep-net catches/sample)

\begin{tabular}{|c|c|c|c|c|c|}
\hline & \multicolumn{2}{|c|}{2015} & \multicolumn{3}{|c|}{2016} \\
\hline Abundance (nr.) & \multicolumn{2}{|c|}{ Total } & \multicolumn{3}{|c|}{ Total } \\
\hline Variants / treatments & V1 & $\mathrm{V} 2$ & $V 1$ & $V 2$ & V3 \\
\hline \multicolumn{6}{|l|}{ Phytophages: } \\
\hline Thrips (Haplothrips tritici) & 98 & 70 & 90 & 6 & 13 \\
\hline Diptera (Oscinella etc.) & 174 & 56 & 62 & 29 & 39 \\
\hline Diptera (Phorbia, Opomyza etc.) & 130 & 89 & 80 & 143 & 168 \\
\hline Oulema melanopus & 29 & 16 & 14 & 9 & 3 \\
\hline Chaetocnema aridula & 21 & 9 & 11 & 4 & 6 \\
\hline Phyllotreta vitulla & 15 & 3 & 39 & 8 & 25 \\
\hline Aphids (Sitobion avenae etc.) & 229 & 347 & 106 & 176 & 132 \\
\hline Leafhoppers (Javesella, Psammottetix s.a.) & 99 & 49 & 92 & 64 & 81 \\
\hline Sun bugs (Eurygaster, Aelia / s.a.) & 15 & 32 & 21 & 15 & 20 \\
\hline Hymenoptera (Cephus, Trachelus) & 2 & & 1 & 7 & \\
\hline Lepidoptera etc. & 1 & & 5 & 1 & 4 \\
\hline Orthoptera & 1 & 1 & 1 & 2 & \\
\hline Diptera (Bibio, Tipula) & 11 & 5 & 2 & & 1 \\
\hline \multicolumn{6}{|l|}{ Entomophages : } \\
\hline Coccinellide (Coccinella 7-punctata) & 6 & 13 & 12 & 2 & 1 \\
\hline Coccinellide (Propylaea14-p.) & 4 & 5 & & 1 & 1 \\
\hline Cantharidae & 33 & 38 & 8 & 7 & 4 \\
\hline Malachiidae & 2 & 1 & 4 & 2 & 2 \\
\hline Nabidae etc. & 33 & 4 & 7 & 5 & 8 \\
\hline Staphylinidae (Tachyporus, Staphylinus) & & & 3 & & \\
\hline Chrysopidae & 5 & 5 & 6 & 2 & 2 \\
\hline Syrphidae & 30 & 139 & 15 & 6 & 7 \\
\hline Empididae (Platypalpus s.a.) & 51 & 41 & 18 & 17 & 8 \\
\hline Hymenoptera (Colyria) & & & 5 & 3 & 1 \\
\hline Hymenoptera (Aphydius) & & & 8 & & \\
\hline Hymenoptera (different parasits) & 30 & 39 & 30 & 17 & 10 \\
\hline Hymenoptera (Formicidae) & 9 & 17 & 9 & 2 & 8 \\
\hline Aranea & 111 & 76 & 98 & 51 & 52 \\
\hline Variants / treatments & V1 & $\mathrm{V} 2$ & V1 & $\mathrm{V} 2$ & V 3 \\
\hline Annual abundance & Total & Total & Total & Total & Total \\
\hline Phytophages & 825 & 685 & 524 & 464 & 492 \\
\hline Entomophages & 314 & 378 & 223 & 115 & 104 \\
\hline Sum of collected arthropods & 1139 & 1063 & 747 & 579 & 596 \\
\hline Report of Phytophages / Entomophages & $2.6 / 1$ & 1.8 / 1 & $2.35 / 1$ & 4.0 / 1 & $4.73 / 1$ \\
\hline
\end{tabular}




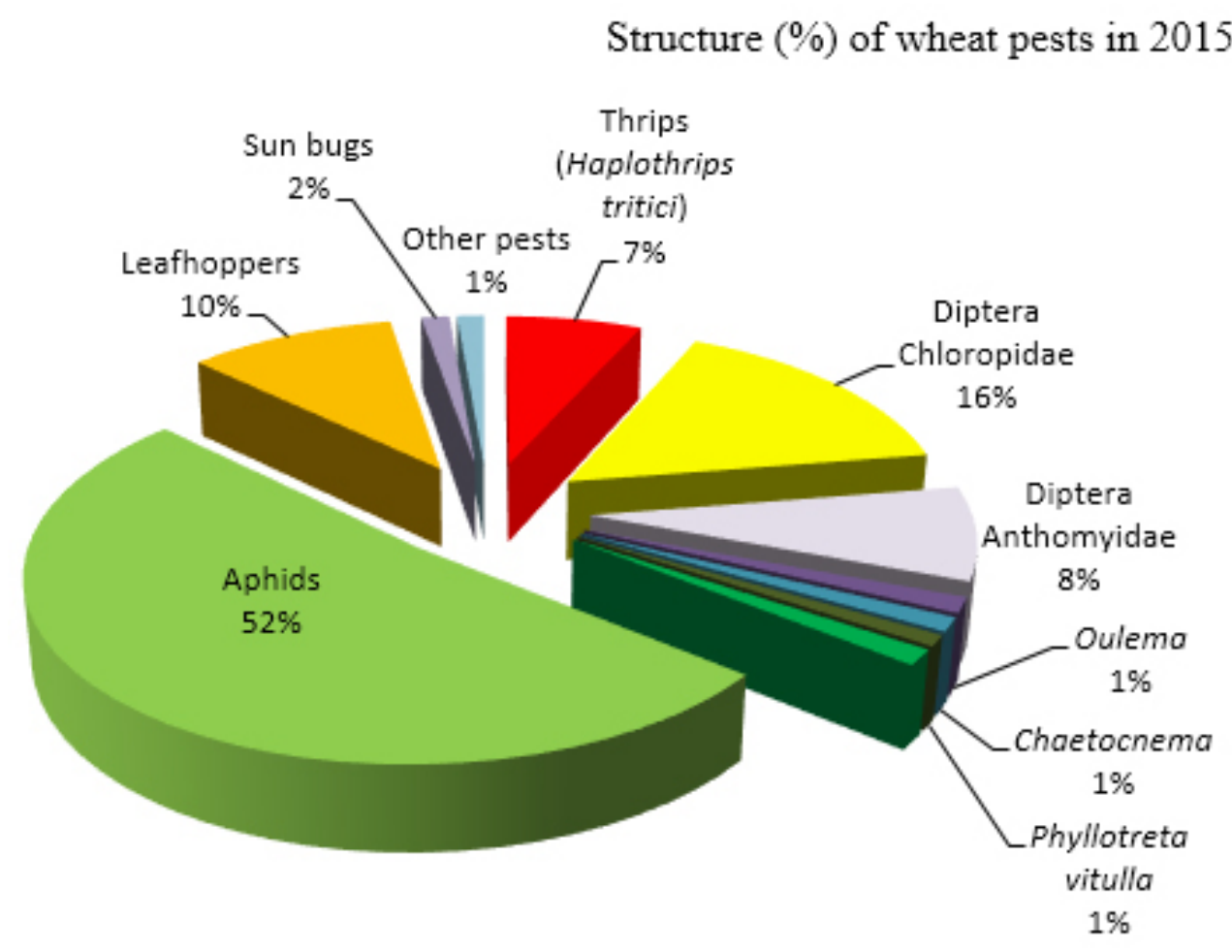

Structure (\%) of wheat pests in 2016

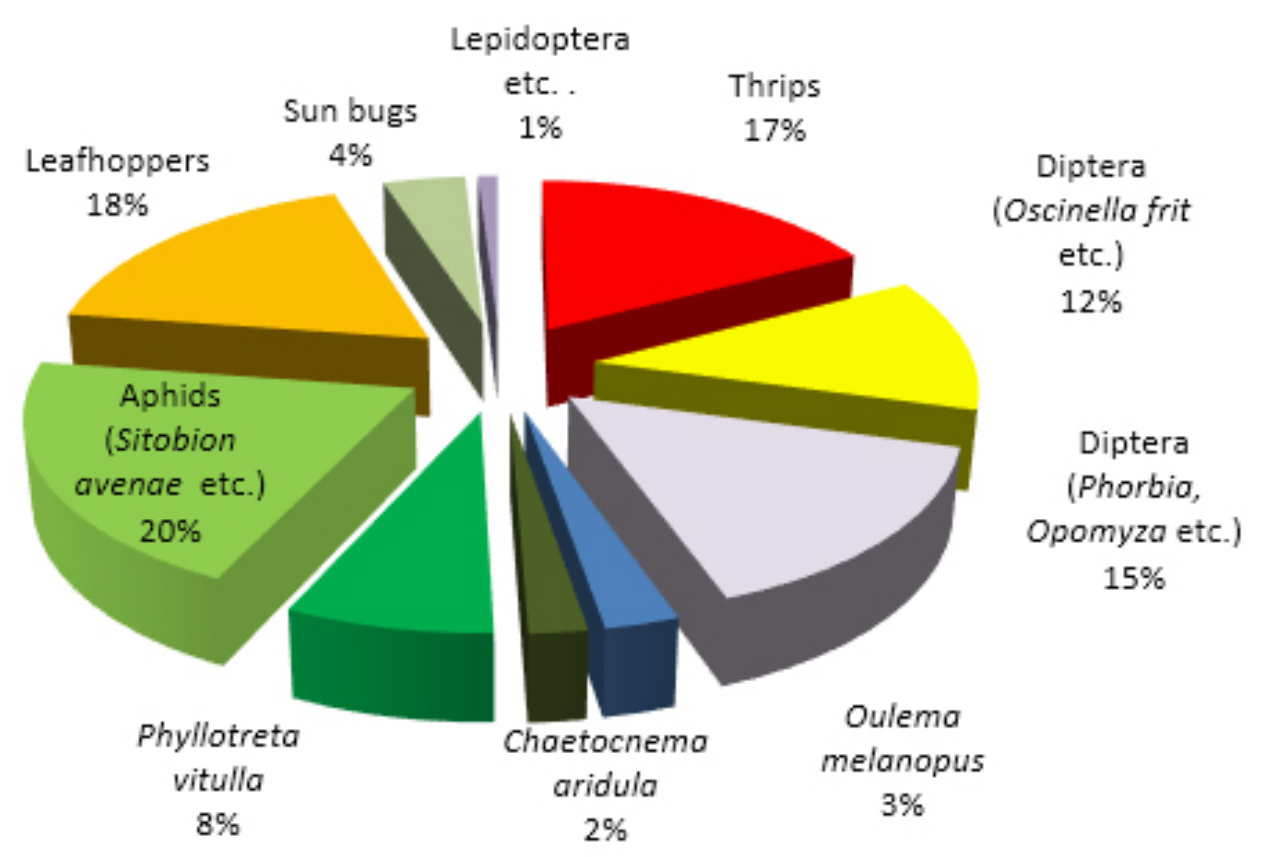

Fig. 2. Structure (\%) of wheat pests in the untreated lots of experimental field at ARDS Turda, in 2015- 2016 


\section{Structure of entomophagous of wheat pests in 2015}

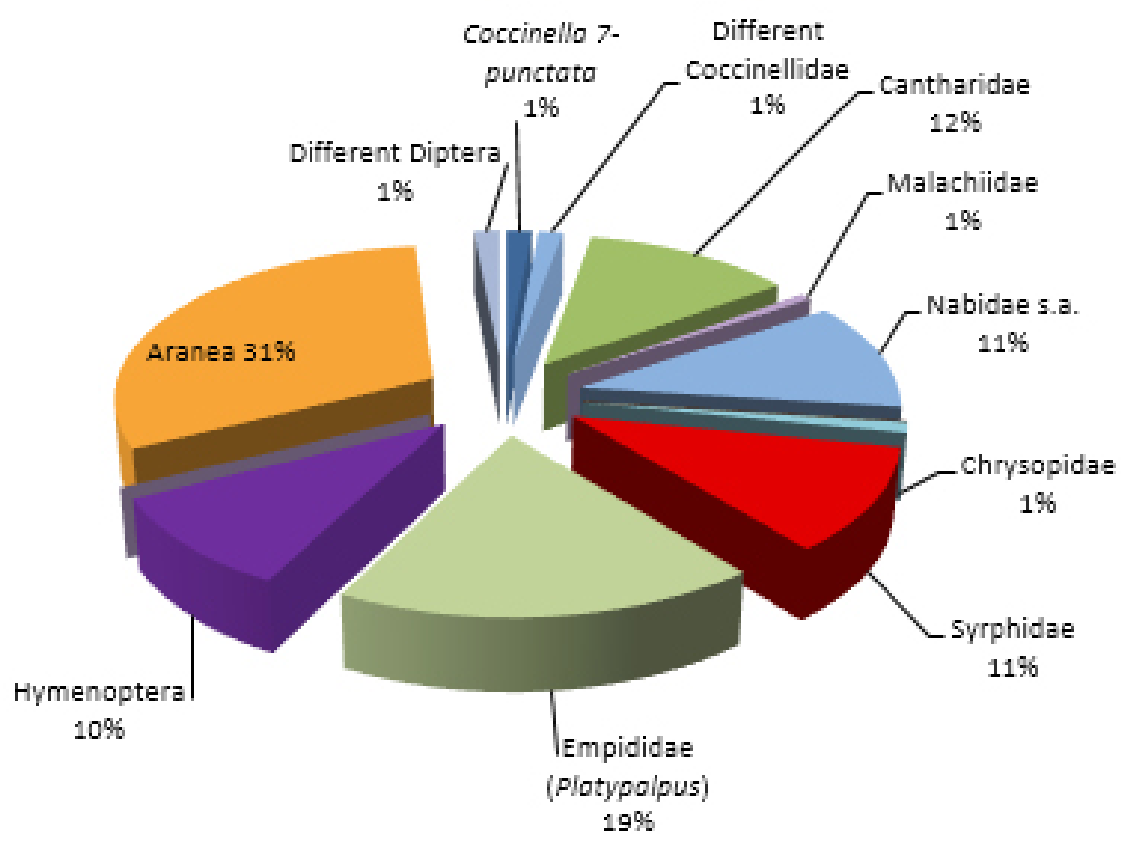

Structure of entomophagousof wheat pests in 2016

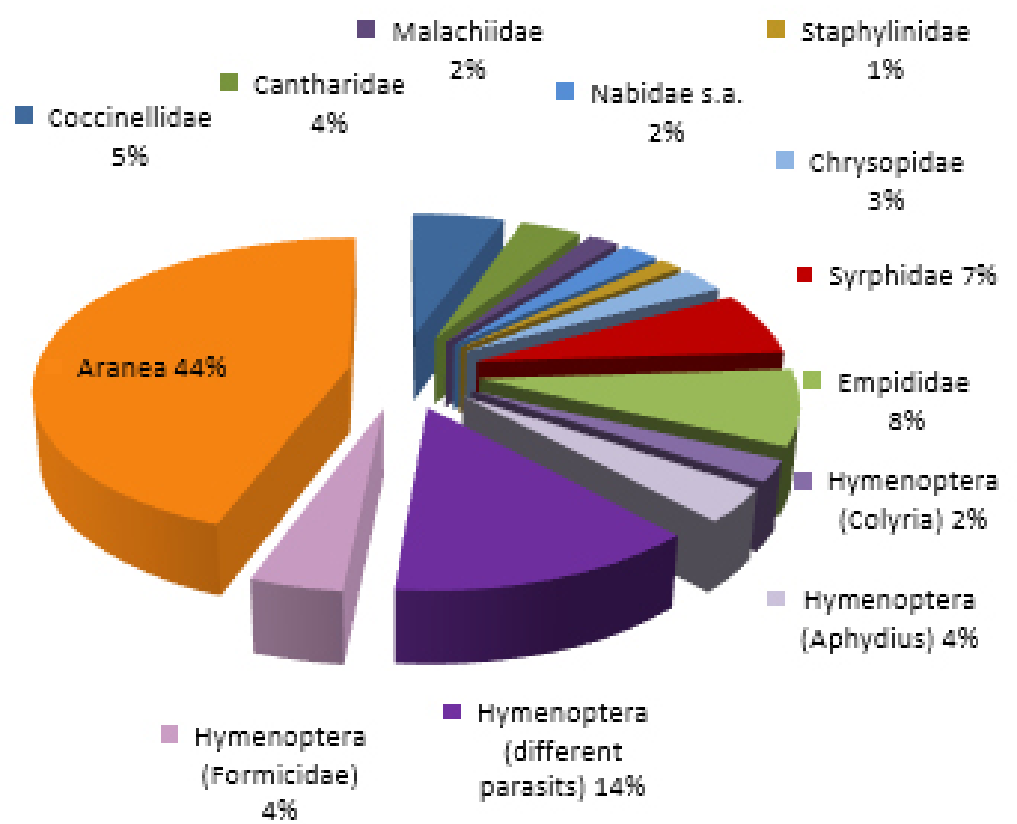

Fig. 3. Structure (\%) of entomophagous arthropods fauna in the untreated lots of experimental wheat field at ARDS Turda, in 2015- 2016 


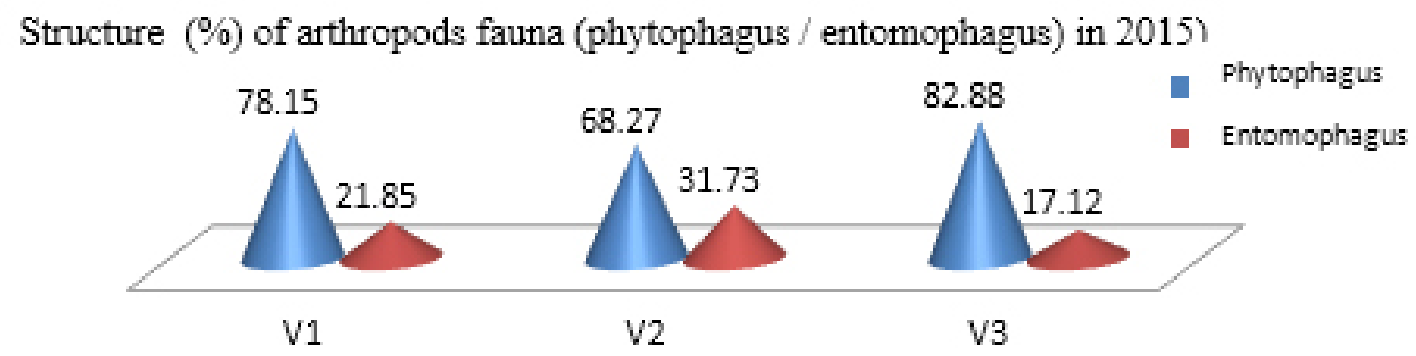

Structure (\%) of arthropods fauna (phytophagus / entomophagus) in 2016)

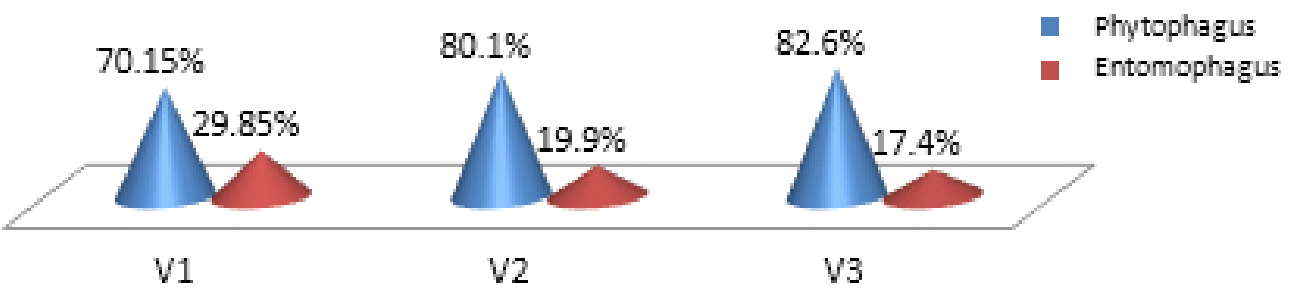

Fig. 4. Structure (\%) of arthropods fauna (phytophagus / entomophagus) depending on insecticide treatments applied at wheat crops (ARDS Turda, 2015 and 2016).

Treatment moments: T1 (at herbicides time) and T2 (at the ear emergence);

Lot variants: $\mathrm{V} 1$ = untreated; $\mathrm{V} 2$ = treated with pyrethroids (Fastac) at T1+T2;

$\mathrm{V} 3=$ treated at $\mathrm{T} 1$ with neonicotinoid (Calypso or Biscaya) $+\mathrm{T} 2$ with pyrethroids (Fastac).

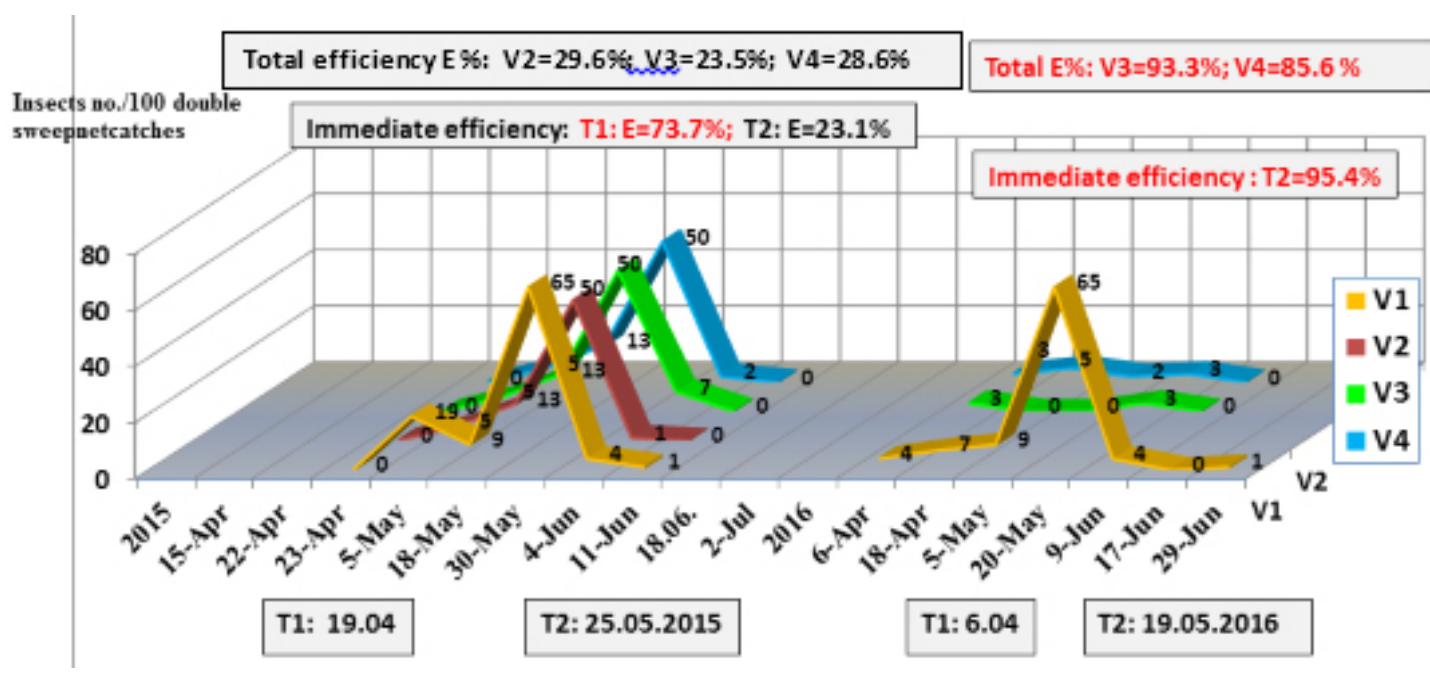

Fig. 5. Abundance and dynamics of wheat thrips (Haplothripstritici) in 2015 and 2016 depending on the insecticide treatment moments: T1 (at the time of herbicides application /19.04.2015 and 6.04.2016) and $\mathrm{T} 2$ (at the ear emergence/25.05.2015 and 19.05.2016),in the variants: $\mathrm{V} 1=$ untreated; $\mathrm{V} 2=$ treated with pyrethroids (Fastac) at T1; V3= treated with yrethroids (Fastac) at T1+T2; V4 treated at T1 with neonicotinoid (Biscaya)+T2 with pyrethroids (Fastac). E\%=efficiency: Immediate efficiency after the T1 or T2 treatment moment; Total efficiency at the end of wheat crop variants V1, V2, V3, V4 and total pest abundance). 


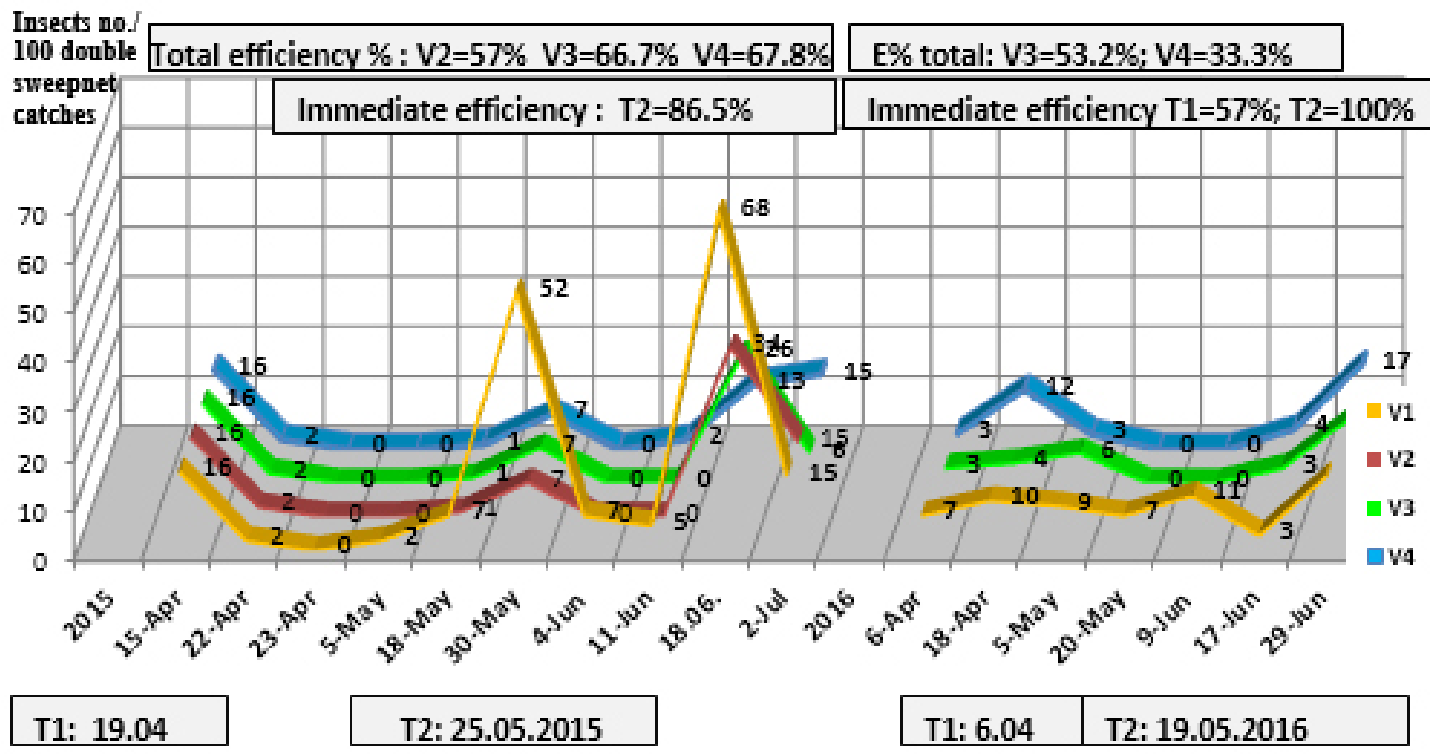

Fig. 6. Abundance and dynamics of wheat flies Chloropidae (Oscinella frit, Meromyza etc.) in 2015 and 2016, depending on the insecticide treatment: T1 (at herbicides application/19.04.2015 and 6.04.2016), T2 (at ear emergence/25.05.2015 and 19.05.2016), in the variants:

$\mathrm{V} 1=$ untreated;V2 = treated with pyrethroids (Fastac) at $\mathrm{T} 1 ; \mathrm{V} 3=$ treated with pyrethroids (Fastac) at $\mathrm{T} 1$ $+\mathrm{T} 2 ; \mathrm{V} 4=$ treated at $\mathrm{T} 1$ with neonicotinoid (Biscaya) + at T 2 with pyrethroids (Fastac); E\%= efficiency: Immediate efficiency after the T1 or T2 treatment moment;

Total efficiency at the end of wheat crop variants V1, V2, V3, V4 and total pest abundance).

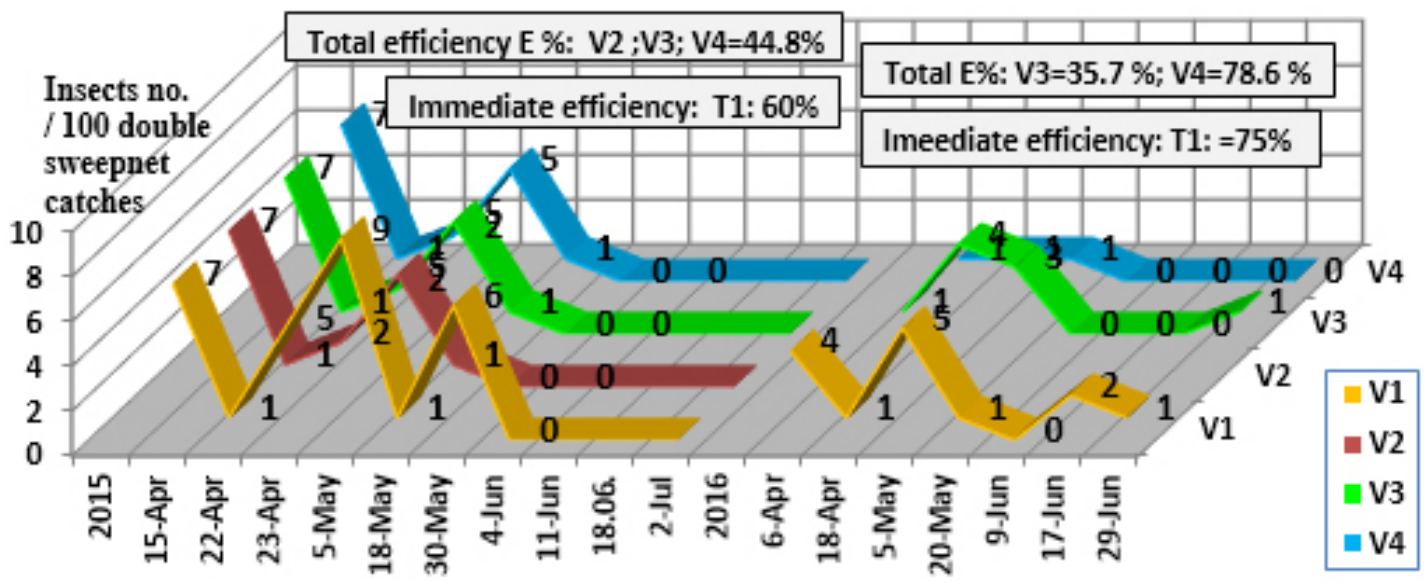

Fig. 7. Abundance and dynamics of leaf beetle (Oulema melanopus) in 2015 and 2016 depending on the insecticide treatment moments: T1 (at the time of herbicides application) and T2 (at the ear emergence); in the variants: V1=untreated; V2=treated with pyrethroids (Fastac) at T1; V3=treated with pyrethroids (Fastac) at T1+T2; V4 treated at T1 with neonicotinoid (Biscaya)+at T2 Fastac. 


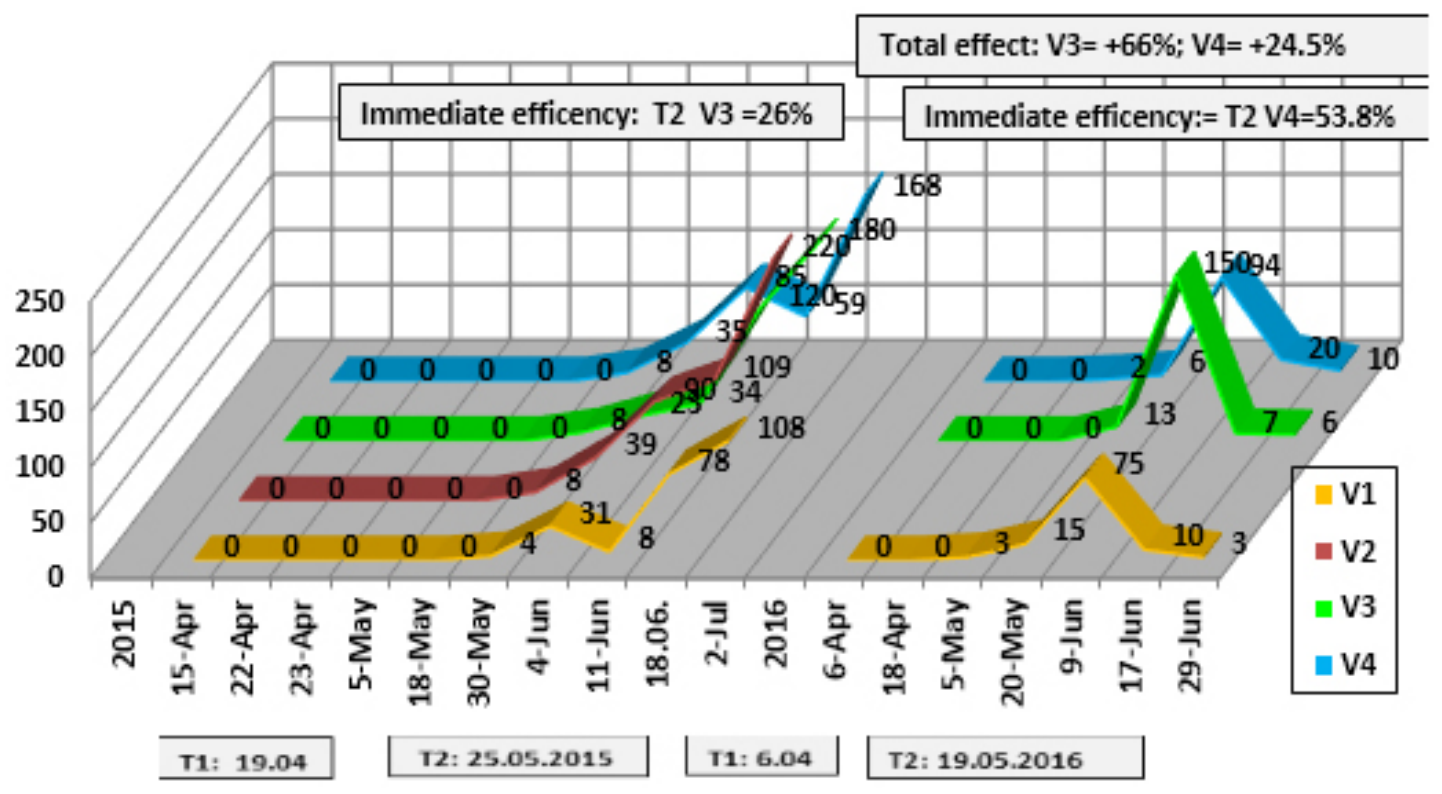

Fig.8. Abundance and dynamics of aphids (Sitobion avenae, Schizaphis graminum, Rhopalosiphum padi etc.) in 2015 and 2016 depending on the insecticide treatment moments: T1 (at the time of herbicides application) and T2 (at the ear emergence); in different variants of plots: V1=untreated;

V2=treated with pyrethroids (Fastac) at T1; V3=treated with pyrethroids (Fastac) at T1 + T2;

V4treated at T1 with neonicotinoid (Biscaya) + at T 2 with pyrethroids (Fastac).

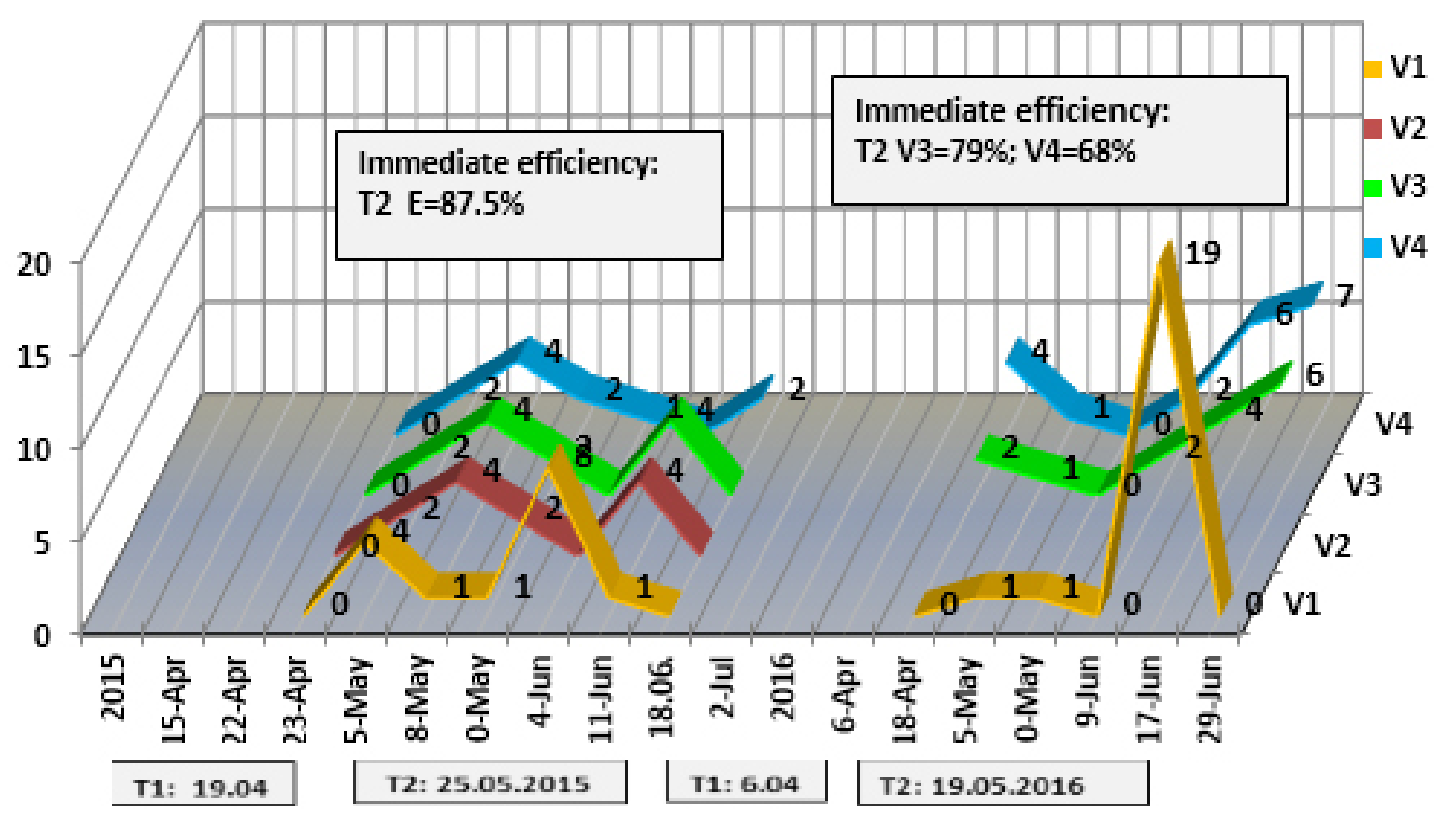

Fig. 9. Abundance and dynamics of sunbugs (Eurygaster maura, Aelia acuminata) in 2015 and 2016 depending on the insecticide treatment moments: T1 (at the time of herbicides application) and T2 (at the ear emergence); in the variants: V1=untreated; V2=treated with pyrethroids (Fastac) at T1; $\mathrm{V} 3=$ treated with pyrethroids (Fastac) at $\mathrm{T} 1+\mathrm{T} 2 ; \mathrm{V} 4=$ treated at $\mathrm{T} 1$ with neonicotinoid (Biscaya) + at $\mathrm{T} 2$ with pyrethroids (Fastac). 
Tab. 3. The table of variance analysis for polifactorial experience: Effect of insecticide treatments applied in integrated technological system for wheat production, in 2015-2016, at ARDS Turda

\begin{tabular}{ccccr}
\hline Variation source & Sum of squares & Freedom degrees & Average square & $\mathrm{F}$ test \\
\hline 1. Years & 0.08178 & 1 & 0.08178 & $9.460(\mathrm{Ft}=19.0)$ \\
\hline 2. Treatments & 7.36463 & 3 & 2.45488 & $58.814^{*}(\mathrm{Ft}=3.49)$ \\
\hline Interaction Years x Treatments & 0.76003 & 3 & 0.25334 & $6.07^{*}(\mathrm{Ft}=3.03)$ \\
\hline Error 1. & 0.01729 & 2 & 0.00865 & \\
\hline Error 2. & 0.50087 & 12 & 0.04174 & \\
\hline Total & 9.06951 & 23 & & \\
\hline
\end{tabular}

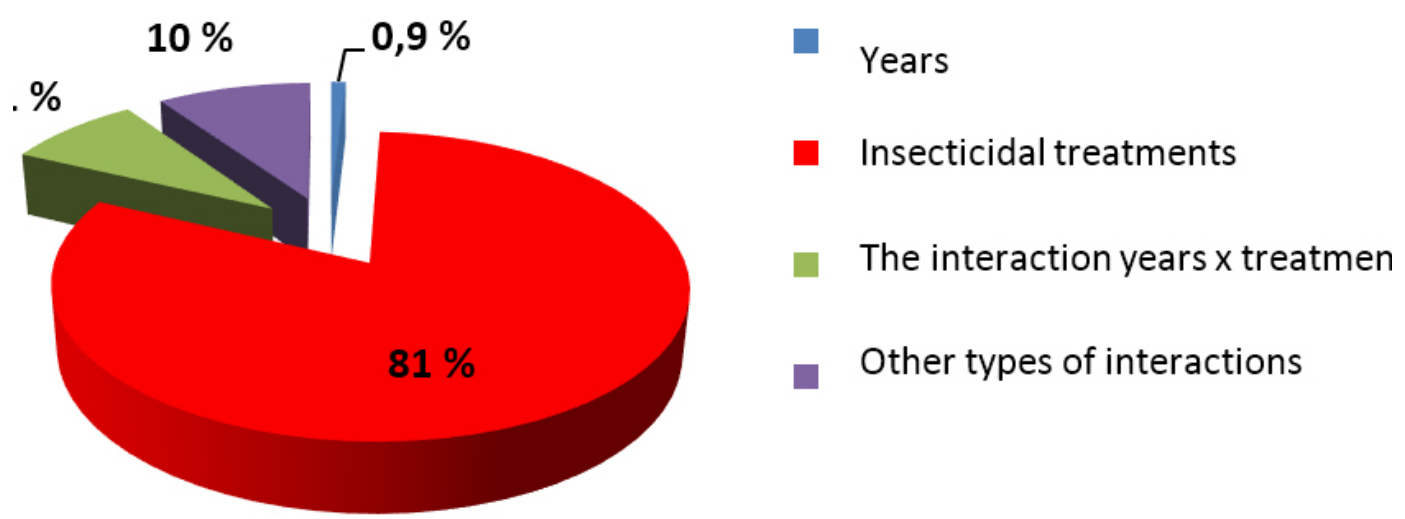

Fig. 10. Contribution (\%) of technological factors on the formation of wheat yield production (ARDS Turda, 2015-2016)

The particular aspects are reported regarding the effect of applied insecticides to the entomophages mortality or on increasing the abundance of some pests in connection with the destroying entomophages. So it can explain, in the case of aphids or phytophagous Diptera, the pests abundance developing in the variants treated with insecticides which determined the mortality of the auxiliaries (Fig. 5, 6, 7, 8, 9).

The percentage contribution (\%) of technological factors on the formation of wheat yield production values indicate the percentage contribution of $81 \%$ for the insecticidal treatments factor. It is finds that in context of studied factors the system with two insecticidal treatments applied at optimal times has been most important contribution to the formation of production, and there are significant differences between variants, statistically assured. The years of vegetation have been a minimal effect. The interaction years $x$ treatments and other interactions into the applied technology have contributed with $8.1 \%$ and $10 \%$ respectively on the formation of wheat yield production (Tab. 3, Fig. 10).

From the data of Tab. 4 is established that into the two years have achieved the highest levels of production $(8.14 \mathrm{t} / \mathrm{ha})$ when applying of two treatments of pyrethroids (V 3) at the moments T1 and T2, with a very significant differences of positive and the average yield increases at $18,6 \%$. For the V4 variant, in which has been applied a neonicotinoid at the T1 moment, the average production level has been 7.47 $\mathrm{t} / \mathrm{ha}$, a very significant of positive with averages increases of $8.8 \%$. But, for this variant, the increasing values of TGW (Thousand grain weight) to $52 \mathrm{~g}$ respective by $4.5 \%$ is distinguished compared to the control, with significant differences and statistically assured.

\section{CONCLUSIONS}

Since 2015, a stronger impact of global warming on the wheat pests structure (\%) are found. The importance of wheat pests is increasing 
Tab. 4. Effect of insecticide treatments on wheat grain yield and on TGW (thousand grain weight), depending on the treatment moments: T1 (at the time of herbicides application) and T2 (at the ear emergence); in different variants of plots: $\mathrm{V} 1=$ untreated; $\mathrm{V} 2=$ treated with pyrethroids at $\mathrm{T} 1 ; \mathrm{V} 3=$ treated with pyrethroids (at T1 + T2; V4 treated at T1 with neonicotinoid + at T2 with pyrethroids, applied in wheat integrated technological system, during 2015-2016, at ARDS Turda

\begin{tabular}{|c|c|c|c|c|c|c|c|c|}
\hline & \multicolumn{4}{|c|}{ Grain yield (t/ha) } & \multicolumn{4}{|c|}{ TGW (g) } \\
\hline Factors and variants & $\begin{array}{c}\text { Grain yield } \\
\text { (t/ha) }\end{array}$ & $\%$ & Dif. & Semnif. & TGW (g) & $\%$ & Dif. & Semnif. \\
\hline \multicolumn{9}{|l|}{ Years Factor } \\
\hline $\begin{array}{l}\text { Average of years } \\
\text { (Control) }\end{array}$ & 7.31 & 100.0 & 0.00 & - & 50.74 & 100.0 & 0.00 & - \\
\hline 2015 & 7.36 & 100.8 & 0.06 & - & 50.16 & 98.9 & -0.58 & - \\
\hline 2016 & 7.25 & 99.2 & -0.06 & - & 51.31 & 101.1 & 0.58 & - \\
\hline DL (p 5\%) & & & 0.16 & & & & 0.87 & \\
\hline DL (p 1\%) & & & 0.38 & & & & 2.00 & \\
\hline DL (p 0.1\%) & & & 1.20 & & & & 6.38 & \\
\hline Testul F (F tab.=19) & $F=9.46$ & & & & $\mathrm{~F}=32.775^{*}$ & & & \\
\hline
\end{tabular}

\begin{tabular}{|c|c|c|c|c|c|c|c|c|}
\hline $\begin{array}{l}\text { Insecticidal treatments } \\
\text { Factor }\end{array}$ & $\begin{array}{l}\text { Grain yield } \\
\text { (t/ha) }\end{array}$ & $\%$ & Dif. & Semnif. & TGW (g) & $\%$ & Dif. & Semnif. \\
\hline V1 & 6.86 & 100.0 & 0.00 & Mt. & 49.78 & 100.0 & 0.00 & Mt. \\
\hline V2 & 6.75 & 98.3 & -0.11 & - & 50.36 & 101.2 & 0.58 & - \\
\hline V3 & 8.14 & 118.6 & 1.28 & $* * *$ & 50.81 & 102.1 & 1.03 & - \\
\hline V4 & 7.47 & 108.8 & 0.60 & $* * *$ & 52.00 & 104.5 & 2.22 & $*$ \\
\hline DL (p 5\%) & & & 0.26 & & & & 1.82 & \\
\hline DL (p 1\%) & & & 0.36 & & & & 2.55 & \\
\hline DL (p 0.1\%) & & & 0.60 & & & & 3.60 & \\
\hline Testul F (F tab.=3.49) & $\mathrm{F}=58.814^{*}$ & & & & $\mathrm{~F}=2.553$ & & & \\
\hline $\begin{array}{l}\text { Interaction years } \mathrm{x} \\
\text { treatments }\end{array}$ & $\begin{array}{l}\text { Grain yield } \\
\text { (t/ha) }\end{array}$ & $\%$ & Dif. & Semnif. & TGW (g) & $\%$ & Dif. & Semnif. \\
\hline \multicolumn{9}{|l|}{2015} \\
\hline V1 & 7.12 & 100.0 & 0.00 & Mt. & 48.23 & 100.0 & 0.00 & Mt. \\
\hline V2 & 6.56 & 92.0 & -0.57 & oo & 50.40 & 104.5 & 2,17 & - \\
\hline V3 & 8.33 & 116.9 & 1.21 & $* * *$ & 49.93 & 103.5 & 1.70 & - \\
\hline V4 & 7.45 & 104.5 & 0.32 & - & 52.07 & 107.9 & 3.83 & ** \\
\hline \multicolumn{9}{|l|}{2016} \\
\hline V1 & 6.61 & 100.0 & 0.00 & Mt. & 51.32 & 100.0 & 0.00 & Mt. \\
\hline V2 & 6.94 & 105.1 & 0.34 & - & 50.32 & 98.1 & -1.00 & - \\
\hline V3 & 7.95 & 120.4 & 1.35 & $* * *$ & 51.68 & 100.7 & 0.36 & - \\
\hline V4 & 7.49 & 113.3 & 0.88 & $* * *$ & 51.93 & 101.2 & 0.61 & - \\
\hline DL (p 5\%) & & & 0.36 & & & & 2.57 & \\
\hline DL (p 1\%) & & & 0.51 & & & & 3.60 & \\
\hline DL (p 0.1\%) & & & 0.72 & & & & 5.09 & \\
\hline Testul F (F tab.=3.03) & $\mathrm{F}=6.07^{*}$ & & & & $\mathrm{~F}=1.750$ & & & \\
\hline
\end{tabular}


in 2015 and 2016, for wheat flies, aphids and leafhoppers, thrips, leaf beetle and wheat fleas, as well as the importance of cereal sunbugs, which requires professional study on the pest dynamics and adequate integrated control of wheat pests.

Entomophagous populations are very active and efficient on the pest natural limitation.

They are particularly abundant and present an important species diversity on the agro-ecosystems.

The integrated pest control system, adequate at the climate changes and eco-technolo-gical facthors, need to contain the application of insecticides (neonicotinoides, pyrethroides), in two moments of treating (at herbicides time and at flag leaf stage and ear appearance).

First insecticidal treatment is recommended in April, at the end of tillering in the 25-33 DC stage (at herbicidal treatment) using systemic insecticides (neonicotinoids) to control wheat flies and wheat fleas (Chaetocnema), Oulema adults, leafhoppers and sun bugs. At this moment, entomophagous were at the beginning of field occurrence and less exposed to insecticides.

The second treatment is recommended at the flag-leaf appearance and ear emergence, in the 4559 DC stage, in May 10-15, to control wheat thrips adults (Haplothrips tritici), aphids, bugs and other pests, using pyrethroids etc. with an immediate control of the pest complex, with along time effect and efficiencies against the development of thrips larvae on the ears, resulting yield increases.

Have been achieved the best results for production on the variants lots treated with pyrethroids, which are an immediate biological efficiency for pests and is protective for entomophagus.

\section{REFERENCES}

1. Malschi D (1995). Protection and use of entomophagous arthropod fauna in cereals. Romanian Agricultural Research 4:93-99.

2. Malschi D (1998). The Identification And Control Of Diptera Pest Species On Wheat Crops. Romanian Agricultural Research 9(10): 75-82.

3. Malschi D (2000). Aspecte actuale privind combaterea gandacului ovăzului (Oulema melanopus L.) in centrul Transilvaniei. Probl. de Protectia Plantelor 27(1): 17-28.

4. Malschi D (2001). Cap. Familia Opomyzidae. Dăunătorii plantelor cultivate. Clasa Insecta: Hymenoptera, Diptera, Clasa Aves şi Mammalia, Editura Academiei Romane Ed: Perju T, Ghizdavu I: 5:365-371.

5. Malschi D (2003). Research on the integrated wheat pests control. (Actual strategy of integrated pests management as part of agroecological system for sustainable development of wheat crop, in Transylvania. Romanian Agricultural Research 19:67- 85.

6. Malschi D (2007). Mediu-agricultură-dezvoltare durabilă şi managementul integrat al dăunătorilor agroecosistemelor cerealiere .Editura Argonaut. p 186.

7. Malschi D (2008).Mediu-agricultură-dezvoltare durabilă. Optimizarea tehnologiilor de management integrat al dăunătorilorgrâului in dinamica modificărilor agroecologice din Transilvania. (Environmentagriculture-sustainable development. Optimization of integrated wheat pest management technologies under the dynamics of agroecological changes in Transylvania). Editura Rgonaut, Cluj-Napoca. ISBN 978-973-109-115-0. p. 315.

8. Malschi D (2009 a). Integrated pest management in relation to environmental sustainability. Part I. Ecological management of wheat pests. Manual online. Faculty of Environmental Sciences, Babeş-Bolyai University. Editura Bioflux Publishing House, Cluj-Napoca. p. 200.

9. Malschi D (2009). Monographical study for the identification and control of diptera pest species on Romanian wheat crops. Abah Bioflux 1(1): 33-47. On line at: http://www.abah.bioflux.com.ro/docs/2009.1.33-47. pdf.

10. Malschi D (2014). Mediu-Biotehnologie-Dezvoltare Durabilă.Biotehnologii şi depoluarea sistemelor ecologice. Manual în format electronic. Facultatea de Ştiinţa şi Ingineria Mediului, Universitatea Babes-Bolyai.Editura Bioflux, ClujNapoca. .ISBN 978-606-8191-71-3 p.190. On line at: http:// www.editura.bioflux.com.ro/docs/2014.Malschi.pdf.

11. Malschi D, Mustea D, Perju T (2003). Homoptere (Aphidina, Cicadina) si importanta lor in agrobiocenozele cerealiere din centrul Transilvaniei. Analele Incda Fundulea. Vol.70. Agris, 2003, p. $221-336$

12. Malschi D, Tritean N, Şerbănescu R (2009). Agricultural and environmental importance of Cean-Boldut antierosional forest belts, in Transylvania. AAB Bioflux -International Journal of the Bioflux Society), 1(1): 1-14. On line at: http:// www.aab.bioflux.com.ro

13. Malschi D, Tritean N, Şerbănescu R (2010). Protective agroforestry belts and their environmental importance for sustainable agriculture development in Transylvania. Romanian Agricultural Research, 27:103-114.

14. Malschi D, Ignea M, Ivas AD, Şimon A, Cheţan C (2011). Dinamica si combaterea integrata a daunatorilor grâului în tehnologia conservativa a solului fără arătură, adecvată schimbărilor climatice actuale.In:Sisteme de lucrări minime ale solului, Al 6-lea Simpozion Internaţional Soil Minimum Tillage Systems, Editura Risoprint, Coord. Guş P. Rusu T 296-308.

15. Malschi D, Ivaş AD, Ignea M (2012). Wheat pests control strategy according to agro-ecological changes in Transylvania. Romanian Agricultural Research. Nardi Fundulea, Romania 29:165-176 On line at: www.incda-fundulea.ro.

16. Malschi D, Ivaş AD, Kadar R (2013 a). Integrated management of wheat aphids and leafhoppers - suitable control methods in Transylvania. Romanian Agricultural 
Research. Nardi. Fundulea, Romania 30: 297-308. On line at: www.incda-fundulea.ro.

17. Malschi D, Ivaș AD, Ignea M, Chețan F,Chețan C (2013 b).Adequate integrated control of wheat pests in notillage conservative system. In: Soil Minimum Tillage Systems, 7th International Symp. USAMV Cluj-Napocas, Proenvironment, 6(14): 332-341. On line at: http:// journals.usamvcluj.ro/index.php/promediu/index.

18. Malschi D, Mureşanu F, Kadar R, Tărău AD, Păcurar A, Chețan C, Tritean N (2014). New entomocoenotic particularities and integrated pest control in Transylvanian wheat crops under the impact of climate warming. The 13th International Symposium "Prospects for the 3rd Millennium Agriculture", Cluj-Napoca, Bulletin UASVM Agriculture, 71(2): 235-246. On line at: http:// www.usamvcluj.ro/symposium.

19. Malschi D, Tărău A, Vălean A, Chețan C, Tritean N (2015 a). Managementul integrat de combatere a dăunătorilor grâului. Agricultura transilvană, nr. 22, martie 2015, I.S.S.N.1454-7287. Statiunea de Cercetare-Dezvoltare Agricola Turda. 82-91.

20. Malschi D, Vălean A, Tărău AD, Dărab ID, Chețan C (2015 b) Noi aspecte privind combaterea integrată a dăunătorilor grâului în condiţiile anului 2015. Agricultura transilvană, nr. 23, 2015, I.S.S.N.1454-7287. Statiunea de CercetareDezvoltare Agricola Turda.

21. Malschi D, Mureșanu F, Kadar R, Tărău AD, Păcurar AM , Chețan C, Tritean C (2015 c). New entomocoenotic particularities and integrated pest control in Transylvanian wheat crops under the impact of climate warming, In: The 13th International Symposium "Prospects for the 3rd Millennium Agriculture, 25th - 26th of September 2014, Cluj-Napoca, publicata in: Buletinul Universităţii de Ştiințe Agricole şi Medicină Veterinară Cluj-Napoca, AcademicPres, Vol. 71 (2)/2014, p.236-246.

22. Malschi D , Ivaş AD, Vălean AM, Chețan F, Tritean N, Chețan N, Pataki I (2015 d), Current importance of wheat pests in the cultural technologies of soil no tillage conservative system and of Antierosional agroforestry curtains system, in Transylvania. In: The 8th International Symposium "Soil Minimum Tillage Systems", 2015, USAMV Cluj-Napoca: ProEnvironment, Editura Bioflux, Vol. 8 (22)/2015, p. 159-169.

23. Malschi D, Mureșanu F, Kadar R, Tărău AD, Vălean AM, Tritean N, Chețan C (2015 e). Environmental public goods associated with agriculture practice of integrated wheat pest management. In: Aes Bioflux (Advances in Environmental Sciences - International Journal of the Bioflux Society), 7(2): 298-308.
24. Malschi D, Tărău AD, Kadar R, Tritean N, Chețan C (2015 f). Climate warming in relation to wheat pest dynamics and their integrated control in Transylvanian crop management systems with no tillage and with agro forestry belts. Romanian Agricultural Research 32: 279289. On line at: www.incda-fundulea.ro

25. Malschi D, Mureșanu F, Vălean AM , Tărău AD, Dărab ID, Kadar R, Chețan F, Tritean N, Chețan C, Patach S (2016 a). Importanța actuală a dăunătorilor grâului în relaţie cu unele elemente tehnologice culturale, în Transilvania. Agricultura transilvană, nr. 24, Februarie 2016, I.S.S.N.1454-7287. Ed. Statiunea de Cercetare-Dezvoltare Agricola Turda. p. 63-71.

26. Malschi D, Vălean AM, Tărău AD, Dărab ID (2016 b). Importanţa rezervei biologice de dăunători, în anul 2016, pentru cultura grâului de toamnă, în Transilvania. Agricultura transilvană, nr. 25, septembrie 2016, I.S.S.N.1454-7287. Ed. Statiunea de Cercetare-Dezvoltare Agricola Turda.

27. Malschi D, Mureșanu F, Tărău AD, Vălean AM, Chețan C, Tritean N (2016 c). Cercetări asupra situaţiilor de risc entomocenotic la cultura grâului, în centrul Transilvaniei. In press. Analele INCDA Fundulea, nr 84/ 2016.

28. Oltean I, Porca M, Ghizdavu I (2004). Entomologie generală. Editura Digital. ISBN 973-7768-01-9.

29. Perju T, Malschi D (2001). Familia Anthomyiidae. In Tratat De Zoologie Agricolă. Dăunătorii plantelor cultivate. Vol.V. Clasa Insecta: Hymenoptera, Diptera, Clasa Aves şi Mammalia, Editura. Acad. Romane, Eds: T.Perju, I.Ghizdavu, 2001, p. 287-337.

30. Perju T, Mustea D, Malschi D (2001). Familia Chlorpidae. In Tratat De Zoologie Agricolă. Dăunătorii plantelor cultivate. Vol. 5. Clasa Insecta: Hymenoptera, Diptera, Clasa Aves și Mammalia, Editura Academiei Romane, Ed.: T.Perju, I.Ghizdavu, 428-447.

31. Popov C., Malschi D, Florica Vilău, Stoica V. (2005). Insect pest management of Lema melanopa in Romania. Romanian Agricultural Research, No.22: p.47-52.

32. Porca Maria Monica, I. Oltean (2004). Ghid practic pentru recunoaşterea şi combaterea dăunătorilor plantelor de cultură. Editura Fundaţia Naţională "Satul Românasc" București, 191 pagini, ISBN 973-86599-2-2

33. Roșca I, Oltean I, Mitrea I, Tãlmaciu M, Petanec DI, .Bunescu H Ș, Rada I, Tãlmaciu N, Stan C, Micu LM (2011). Tratat de Entomologie, generalã şi specialã. Editura "Alpha MDN", Buzău, 2011 